\title{
Multiphase Reactivity of Gaseous Hydroperoxide Oligomers Produced from Isoprene Ozonolysis in the Presence of Acidified Aerosols
}

Matthieu Riva ${ }^{\dagger, 1}$, Sri H. Budisulistiorini ${ }^{\dagger, 2}$, Zhenfa Zhang ${ }^{\dagger}$, Avram Gold ${ }^{\dagger}$, Joel A. Thornton ${ }^{\ddagger}$, Barbara J. Turpin ${ }^{\dagger}$, and Jason D. Surratt ${ }^{\dagger *}$

${ }^{\dagger}$ Department of Environmental Sciences and Engineering, Gillings School of Global Public Health, The University of North Carolina at Chapel Hill, Chapel Hill, North Carolina 27599 United States

${ }^{¥}$ Department of Atmospheric Sciences, University of Washington, Seattle, Washington 98195 United States

${ }^{1}$ Now at the Department of Physics, University of Helsinki, Finland

${ }^{2}$ Now at the Earth Observatory of Singapore, Nanyang Technological University, Singapore

* To whom correspondence should be addressed.

Jason D. Surratt, Department of Environmental Sciences and Engineering, Gillings School of Global Public Health, University of North Carolina at Chapel Hill, Chapel Hill, NC 27599 USA. Tel: 1-(919)-966-0470; Fax: (919)-966-7911; Email: surratt@unc.edu

The authors declare no conflict of interest.

Keywords: HOMs, heterogeneous reaction, Criegee, HR-ToF-CIMS, SOA 


\begin{abstract}
Ozonolysis of alkenes results in the formation of primary ozonides (POZs), which can subsequently decompose into carbonyl compounds and stabilized Criegee intermediates (sCIs). The sCIs generated from isoprene ozonolysis include the simplest congener, formaldehyde oxide $\left(\mathrm{CH}_{2} \mathrm{OO}\right)$, and isomers of $\mathrm{C}_{4}$-sCI. Although the bimolecular reaction with $\mathrm{H}_{2} \mathrm{O}$ is expected to be the main fate of sCIs, it was reported that sCIs can also react with carboxylic acids and/or organic hydroperoxides leading to gas-phase oligomeric compounds. While the impact of the gas-phase composition $\left(\mathrm{H}_{2} \mathrm{O}\right.$, sCI scavenger) on the formation of such products was recently studied, their fate remains unclear. In the present work, formation of oligomeric hydroperoxide from isoprene ozonolysis, proposed as reaction products composed of the sCI as a chain unit and formed from the insertion of $\mathrm{sCI}$ into a hydroperoxide or a carboxylic acid, was systematically examined in the presence of aerosol with varying compositions. The effect of hydroxyl $(\mathrm{OH})$ radicals on the gas- and particle-phase compositions was investigated using diethyl ether as an $\mathrm{OH}$ radical scavenger. Thirty-four oligomeric compounds resulting from the insertion of sCIs into organic hydroperoxides or carboxylic acids were identified using iodide chemical ionization high-resolution mass spectrometry. Large reactive uptake onto acidified sulfate aerosol was observed for most of the characterized gaseous oligomeric species, whereas the presence of organic coatings and the lack of aerosol water significantly reduced or halted the reactive uptake of these species. These results indicate that highly oxidized molecules, such as hydroperoxides, could undergo multiphase reactions, which are significantly influenced by the chemical composition of seed aerosol. Furthermore, in addition to functionalization and accretion, decomposition and revolatilization should be considered in the SOA formation.
\end{abstract}




\section{Introduction}

Isoprene (2-methyl-1,3-butadiene, $\mathrm{C}_{5} \mathrm{H}_{8}$ ) is the most abundant non-methane hydrocarbon

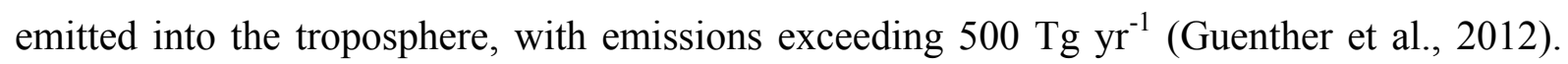
Atmospheric oxidation of isoprene occurs mainly by reaction with hydroxyl $(\mathrm{OH})$ radical during the daytime, whereas nighttime oxidation can also occur by ozone $\left(\mathrm{O}_{3}\right)$ or nitrate $\left(\mathrm{NO}_{3}\right)$ radical. In addition, recent studies have also reported that multiphase chemistry of isoprene in wet acidic aerosols or cloud droplets could be an important source of SOA (Wang et al., 2012; Kameel et al., 2013; Szmigielski, 2016). Recent studies have shown that the OHinitiated oxidation of isoprene under low-nitric oxide (NO) conditions contributes significantly to secondary organic aerosol (SOA) formation on a global scale through multiphase chemistry of isoprene epoxydiols (IEPOX) (Surratt et al., 2010; Budisulistiorini et al., 2013; Chen et al., 2015; Hu et al., 2015, Xu et al., 2015; Rattanavaraha et al., 2016). While the reaction with ozone globally removes $\sim 10 \%$ of isoprene, the contribution of isoprene ozonolysis to the SOA budget has been concluded as negligible on the basis of low SOA yields (in the range of $0.1-1.4 \%$ ) determined from high concentration smog chamber experiments in the absence of seed aerosol or with non-acidified seed aerosol (Hasson et al., 2001; Kleindienst et al. 2007; Sato et al., 2013). Jang et al. (2002) and Czoschke et al. (2003) reported that aerosol acidity enhanced SOA formation from isoprene ozonolysis, but the SOA yields remained low. We have recently reported the presence of organosulfates (OSs) and 2methyltetrols in laboratory-generated SOA formed from isoprene ozonolysis and observed that these SOA constituents were significantly enhanced in the presence of acidic sulfate aerosols (Riva et al., 2016a). In addition, many of the laboratory-generated SOA constituents were measured for the first time in ambient aerosol samples collected from the southeastern United States, suggesting that isoprene ozonolysis could contribute to SOA formation in the atmosphere in the presence of acidic sulfate aerosol (Riva et al., 2016a). 
Isoprene ozonolysis is similar to that of other unsaturated hydrocarbons. $\mathrm{O}_{3}$ addition occurs at one of the two double bonds of isoprene to form a primary ozonide (POZ). POZs subsequently decompose to carbonyl compounds and carbonyl oxides, with a fraction of the latter collisionally deactivated, yielding stabilized Criegee intermediates (sCI) (Johnson and Marston, 2008). The sCIs generated from isoprene ozonolysis include the simplest formaldehyde oxide $\left(\mathrm{CH}_{2} \mathrm{OO}\right)$ bi-radical and isomers of $\mathrm{C}_{4}$-sCIs (Scheme $\left.\mathrm{S} 1\right)$. Methacrolein (MACR) and methyl vinyl ketone (MVK), which are major first-generation oxidation products from isoprene ozonolysis (Kamens et al., 1982; Sauer et al., 1999), can further react with $\mathrm{O}_{3}$ and lead to $\mathrm{C}_{3}$-sCIs (Scheme $\mathrm{S} 1$ ). Generally, Criegee intermediates are initially formed in the excited state and thus a fraction can isomerize to organic hydroperoxides, carboxylic acids, or fragment to smaller products (including $\mathrm{OH}$ radicals) in addition to formation of sCIs. In the case of isoprene ozonolysis, the sCI yields in the range of 0.56 to 0.60 have been measured (Zhang et al., 2002; Sipila et al., 2014; Newland et al., 2015; Nguyen et al., 2016). This suggests that large quantities of sCIs are generated from isoprene ozonolysis, leading to the hypothesis that sCIs formed from the ozonolysis of biogenic alkenes can add to the oxidation capacity of the atmosphere (Berndt et al., 2012; Mauldin III et al., 2012; Welz et al., 2012). Due to the relatively long lifetimes of sCIs ( $1 \mathrm{~s})$, bimolecular reactions of sCIs with atmospheric compounds, such as $\mathrm{H}_{2} \mathrm{O}, \mathrm{SO}_{2}$, carbonyls, and organic acids, are possible (Neeb et al., 1997; Welz et al., 2012, 2014; Berndt et al., 2012, 2014a, b; Taatjes et al., 2012, 2013; Sipila et al., 2014). However, it is worth noting that $\mathrm{H}_{2} \mathrm{O}$ vapor is expected to strongly influence the fate of sCIs in the troposphere (Newland et al., 2015; Nguyen et al., 2016).

Many studies have reported gas-phase products from isoprene ozonolysis, including carbonyls, organic hydroperoxides, and organic acids (Kamens et al., 1982; Neeb and Moortgat, 1999; Sauer et al., 1999; Huang et al., 2013; Nguyen et al., 2010; 2016). The 
formation of such products was proposed to occur through the reaction of sCIs with $\mathrm{H}_{2} \mathrm{O}$. More recently it was proposed that the formation of oligomeric hydroperoxides identified in the gas phase and proposed as product composed of the $\mathrm{sCI}$ as a chain unit, proceeds through the reaction of sCIs with carboxylic acids and/or organic hydroperoxides (Nguyen et al., 2010; Sakamoto et al., 2013; Inomata et al., 2014). These studies have been performed either in the absence or with non-acidified seed particles. However, multiphase chemistry might be expected since it was recently reported that oxygenated species derived from isoprene oxidation, such as epoxides (Surratt et al., 2010; Lin et al., 2012) and organic hydroperoxides (Liu et al., 2016; Riva et al., 2016b) undergo subsequent multiphase chemical reactions leading to gas- and particle-phase products.

In this study we investigate the ozonolysis of isoprene in the presence of sulfate seed aerosols of varying acidity and composition, with a specific focus on the formation and multiphase reactions of gas-phase hydroperoxide oligomers. Because of the high yield of $\mathrm{OH}$ radicals from isoprene ozonolysis, experiments were conducted both in the presence and absence of an $\mathrm{OH}$ radical scavenger. Gas-phase products were characterized using an Aerodyne high-resolution time-of-flight chemical ionization mass spectrometer (HR-ToFCIMS) equipped with iodide reagent ion chemistry. In addition, aerosol filters collected from indoor smog chamber experiments were analyzed by ultra performance liquid chromatography/electrospray ionization high-resolution quadrupole time-of-flight mass spectrometry (UPLC/ESI-HR-QTOFMS). Our results indicate that oligomeric products formed from the gas-phase reaction of sCIs with carboxylic acids and/or hydroperoxides undergo further acid-catalyzed reactive uptake in the presence of acidified sulfate seed aerosols. The presence of oligomeric compounds, OSs and 2-methyltetrols in the particle phase suggests that such multiphase chemical reactions lead to isoprene-derived SOA products from the ozonolysis of isoprene. 


\section{Experimental Section}

\subsection{Chamber Experiments.}

Isoprene ozonolysis experiments were conducted in a $10-\mathrm{m}^{3}$ Teflon chamber at the University of North Carolina under dark and dry conditions $(3.3 \pm 0.25 \%, \mathrm{RH})$ at $296 \pm 1 \mathrm{~K}$. Detailed operating procedures for this chamber facility have been previously described (Lin et al., 2012). Experiments were conducted as mentioned in our recent study (Riva et al., 2016a) and a summary of the experimental conditions is provided in Table S1. Briefly, $\sim 100 \mathrm{ppb}$ of isoprene (Sigma-Aldrich, 99\%) was introduced into the chamber by passing a heated nitrogen $\left(\mathrm{N}_{2}\right)$ stream through a heated glass manifold. For selected experiments, $\sim 35 \mathrm{ppm}$ of diethyl ether was injected following the same procedure to serve as an $\mathrm{OH}$ radical scavenger (Sato et al., 2013). Concentrations of isoprene and diethyl ether were measured every 10 minutes with an online gas chromatography/flame ionization detector (GC-FID, Model CP-3800, Varian), which was calibrated using multiple injections of isoprene and diethyl ether. Approximately 1 hour after isoprene injection, $120-150 \mathrm{ppb}$ of $\mathrm{O}_{3}$ was introduced into the chamber using an $\mathrm{O}_{3}$ generator (Model L21, Pacific ozone). $\mathrm{O}_{3}$ concentration was monitored over the course of experiments using a UV photometric analyzer (Model 49P, Thermo-Environmental).

Non-acidified or acidified ammonium or magnesium sulfate seed aerosols were introduced in the chamber two hours after $\mathrm{O}_{3}$ injection. Non-acidified seed aerosol was generated from $0.06 \mathrm{M}$ magnesium sulfate $\left(\mathrm{MgSO}_{4}\right)$ or ammonium sulfate $\left.\left(\mathrm{NH}_{4}\right)_{2} \mathrm{SO}_{4}\right)_{(\mathrm{aq})}$ solutions and acidified seed aerosol from $0.06 \mathrm{M}\left(\mathrm{MgSO}_{4}\right)_{(\mathrm{aq})}$ or $\left.\left(\mathrm{NH}_{4}\right)_{2} \mathrm{SO}_{4}\right)_{(\mathrm{aq})}+0.06 \mathrm{M}$ $\left(\mathrm{H}_{2} \mathrm{SO}_{4}\right)_{(\mathrm{aq})}$ solutions. Aerosol size distributions were continuously measured using a differential mobility analyzer (DMA, BMI model 2002) coupled to a mixing condensation particle counter (MCPC, BMI model 1710) in order to monitor aerosol number, surface area, and volume concentrations within the chamber. Once aerosol volume concentrations stabilized ( $\sim 1$ hour after reaction), aerosols were collected onto 47-mm diameter Teflon 
filters (1.0- $\mu \mathrm{m}$ pore size, Tisch Environmental, EPA $\mathrm{PM}_{2.5}$ membrane) for two hours at a sampling flow rate of $25 \mathrm{~L} \mathrm{~min}^{-1}$ to characterize particle-phase reaction products.

\subsection{Chemical Characterization of Gas- and Particle-Phase Constituents.}

Real-time measurements of gas-phase oxidation products from isoprene ozonolysis were performed with an Aerodyne high-resolution time-of-flight chemical ionization mass spectrometer (HR-ToF-CIMS), equipped with iodide $\left(\mathrm{I}^{-}\right)$reagent ion chemistry. Analyses were restricted to ions containing an iodide adduct, which guarantees detection of the parent organic compound without substantial fragmentation. Iodide-HR-ToF-CIMS has been described previously and demonstrated high sensitivity towards multifunctional oxygenated organic compounds in the gas and particle phases (Lee et al., 2014; Lopez-Hilfiker et al., 2016a,b). Typical intensities of $\mathrm{I}^{-}$and $\mathrm{IH}_{2} \mathrm{O}^{-}$were $8.0 \times 10^{+8}$ and $2.5 \times 10^{+7}$ ion $\mathrm{s}^{-1}$, respectively. Therefore, due to the small abundance of the water cluster, the impact of the water cluster in the clustering of organic compounds is expected to be negligible.

Chemical characterization of SOA constituents produced from isoprene ozonolysis was performed by UPLC/ESI-HR-QTOFMS (6520 Series, Agilent) operated in both negative and positive ion modes. Operating conditions have been described in detail elsewhere (Lin et al., 2012). Filters collected from smog chamber experiments were extracted with $22 \mathrm{~mL}$ of high-purity methanol (LC-MS CHROMASOLV-grade, Sigma-Aldrich) by sonication for 45 min. The methanol extracts were then blown dry under a gentle $\mathrm{N}_{2}(\mathrm{~g})$ stream at ambient temperature. Dried extracts were reconstituted with $150 \mu \mathrm{L}$ of a 50:50 (v/v) solvent mixture of methanol (LC-MS CHROMASOLV-grade, Sigma-Aldrich) and high-purity water (Milli-Q, 18.2 M $\Omega$ ). Five or $10 \mu \mathrm{L}$ aliquots were injected onto the UPLC column (Waters ACQUITY UPLC HSS T3 column, $2.1 \times 100 \mathrm{~mm}, 1.8 \mu \mathrm{m}$ particle size) and eluted at a flow rate of 0.3 $\mathrm{mL} \min ^{-1}$ with a solvent mixture of methanol containing $0.1 \%$ acetic acid or $0.1 \%$ ammonium 
acetate (LC-MS CHROMASOLV-grade, Sigma-Aldrich) and water containing $0.1 \%$ acetic acid or $0.1 \%$ ammonium acetate (LC-MS CHROMASOLV-grade, Sigma-Aldrich) for negative and positive ion modes, respectively.

\section{Results and Discussion}

\subsection{Chemical Characterization of Gas-Phase Reaction Products.}

Chemical characterization of gas-phase reaction products generated from isoprene ozonolysis has been performed using a large variety of analytical techniques, including proton transfer reaction-mass spectrometry (PTR-MS), CIMS, and GC-FID (Kamens et al., 1982; Neeb and Moortgat, 1999; Sauer et al., 1999; Inomata et al., 2014; Nguyen et al., 2016). These studies reported the formation of volatile species, such as gas-phase hydroperoxides, carbonyls and carboxylic acids. Recent development of new reagent ion chemistries for CIMS, such as $\mathrm{I}^{-}$or nitrate $\left(\mathrm{NO}_{3}{ }^{-}\right)$, has allowed for the measurement of highly oxidized molecules (HOMs) in both gas (Ehn et al., 2014; Lee et al., 2014; Krechmer et al., 2015; Bianchi et al., 2016) and particle phases (Lopez-Hilfiker et al., 2016a,b). We further characterized the gas-phase products formed from isoprene ozonolysis by iodide-HR-ToF-CIMS, leading to the identification of more than 50 gas-phase oxidation products. Products are classified into four groups: hydroperoxides (Group 1), oligomeric hydroperoxides (Group 2), summarized in Table 1, and carboxylic acids (Group 3), oligomeric carboxylic acids (Group 4), summarized in Table S2. It should be pointed out that, as discussed by Lee et al., (2014), the formation of carboxylate anions (anions that are not complexes with $\mathrm{I}^{-}$) as well as secondary ion chemistry are possible, leading to a complexity in the separation and/or identification of organic products by iodide-HR-ToF-CIMS. In this study, only iodide-adduct products were considered. In addition, as shown in Figure S1, no significant new particle formation (NPF) was observed in the conditions used in this study. NPF (2000-3000 particles $\mathrm{cm}^{-3}$ ) was 
observed only in the experiments performed without an $\mathrm{OH}$ radical scavenger (Figure S1a). Therefore, potential formation of observed products through chemistry in the aerosols followed by product volatilization can be ruled out (Lim and Ziemann, 2009).

Group 1 is comprised of gas-phase organic hydroperoxides, designated hydroxyalkyl hydroperoxides (HAHPs), formed by isoprene ozonolysis and reaction of the resulting sCIs with water (Kroll and Seinfeld, 2008; Huang et al., 2013). This pathway likely explains the six HAHPs reported in Table 1 (Neeb and Moortgat, 1999; Sakamoto et al., 2013; Inomata et al., 2014; Nguyen et al., 2016). Larger formation of HAHPs could be likely expected by additional gas-phase water. Organic hydroperoxides formed from the $\mathrm{OH}$ oxidation of isoprene, e.g. isoprene hydroxyhydroperoxides (ISOPOOH), are not included in Table 1. As discussed later in the manuscript, the addition of the radical scavenger diethyl ether leads to a significant decrease of the $\mathrm{OH}$-initiated oxidation products and supports the assignment of the identified compounds as isoprene ozonolysis products.

The Group 2 is comprised of oligomeric hydroperoxides formed from the reaction of organic hydroperoxides with sCIs. The formation of such oligomers was proposed to occur through the insertion of a sCI into an organic hydroperoxide, as presented in Scheme S2 (Inomata et al., 2014). Eleven oligomeric hydroperoxides identified from isoprene ozonolysis are reported in Table 1. Among the eleven oligomers, six correspond to the insertion of the simplest $\mathrm{C}_{1}$-sCI, formaldehyde oxide $\left(\mathrm{CH}_{2} \mathrm{OO}\right)$, into the HAHPs in Group 1. In addition, products at $\mathrm{m} / z 277\left(\mathrm{C}_{5} \mathrm{H}_{10} \mathrm{O}_{5} \mathrm{I}^{-}\right)$and $293\left(\mathrm{C}_{5} \mathrm{H}_{10} \mathrm{O}_{6} \mathrm{I}^{-}\right)$are proposed to result from the insertion of a $\mathrm{C}_{4}$-sCI into HMHP and HPMP, respectively. Finally, insertion of two $\mathrm{C}_{1}$-sCIs into HPFOR, HMHP and HPMP lead to the formation of ions at $m / z 281\left(\mathrm{C}_{3} \mathrm{H}_{6} \mathrm{O}_{7} \mathrm{I}^{-}\right), 283$ $\left(\mathrm{C}_{3} \mathrm{H}_{8} \mathrm{O}_{7} \mathrm{I}^{-}\right)$and $299\left(\mathrm{C}_{3} \mathrm{H}_{8} \mathrm{O}_{8} \mathrm{I}^{-}\right)$. No products resulting from the insertion of $\mathrm{C}_{3}$-sCI into organic hydroperoxides were observed, suggesting that the ozonolysis of primary products (Scheme S1) was negligible under our experimental conditions. 
Previous studies have reported large yields of carboxylic acids in both gas (Orzechowska and Paulson, 2002; Inomata et al., 2014) and particle phases (Nguyen et al., 2010) from isoprene ozonolysis. Ten carboxylic acids were identified in the gas-phase, including formic and pyruvic acids, and represent the third group of compounds identified in this study (Table S2). Pathways leading to the carboxylic acids reported in Table S2 have been proposed previously by Nguyen et al. (2010) to occur from the ozonolysis of isoprene though the "hydroperoxide channel" or via the ozonolysis of first generation products such as acrylic acid.

Group-4 includes oligomeric compounds that arise from the insertion of sCIs into carboxylic acids (Scheme S3), resulting in polymeric hydroperoxides (Nguyen et al., 2010; Sakamoto et al., 2013; Inomata et al., 2014). Twenty-five gaseous polymeric products were identified from isoprene ozonolysis and are reported in Table S2. Among them, eight correspond to the reaction of carboxylic acids with the $\mathrm{CH}_{2} \mathrm{OO}$ bi-radical and nine with the $\mathrm{C}_{4}$-sCI. The insertion of two sCIs was also observed for nine compounds, as reported in Table $\mathrm{S} 2$. Higher reactivity of $\mathrm{C}_{4}$-sCI have been observed with the carboxylic acids, in line with rate coefficients determined for the reactions of sCIs with acids and other organic compounds (Novelli et al., 2014). Rate coefficients for the reaction of sCIs with carboxylic acids were calculated to be two orders of magnitude greater $\left(10^{-10} \mathrm{~cm}^{3} \mathrm{~s}^{-1}\right)$ than those for reaction of sCIs with other carbonyls or hydroperoxides $\left(10^{-12} \mathrm{~cm}^{3} \mathrm{~s}^{-1}\right)$ (Novelli et al., 2014). Since the aim of this study was to investigate the formation and multiphase chemistry of isoprene-derived ozonolysis products, products generated from the $\mathrm{OH}$-initiated oxidation of isoprene are not reported in Tables 1 and S2. It could be expected that products belonging to group- 2 will be strongly reduced by the presence of additional gas-phase water. On the contrary, products from group-4 will likely remain formed even at larger $\mathrm{RH}$, notably due to the large reactivity of sCI with carboxylic acids (Novelli et al., 2014; Welz et al., 2014). 


\subsection{Chemical Characterization of Particle-Phase Reaction Products.}

Tables S3 and S4 summarize the isoprene-derived SOA products identified by UPLC/ESIHR-QTOFMS operated in positive and negative ion modes, respectively. As discussed in Riva et al. (2016a), IEPOX-derived SOA products were identified in the experiments performed only in the absence of an $\mathrm{OH}$ radical scavenger. Concentrations of the polymeric products identified in particle phase reported here (Figure S2) along with the 2-methyltetrols and OSs reported in Riva et al. (2016a) are significantly enhanced by the presence of acidified particles (Lin et al., 2012, Riva et al., 2016a). Eighteen compounds identified in the gas-phase were also observed in the particle phase but their low abundances (i.e. signal/noise $<3$ ) preclude quantification of these products. Direct comparison of the gas- and particle-phase concentrations was not possible due to absence of the appropriate calibration standards. Quantification of compounds observed in the positive ion mode was accomplished using 1,2ISOPOOH and 2-methyltetrols synthesized in-house (Budisulistiorini et al., 2015; Riva et al., 2016b) as surrogate standards, resulting in large uncertainties for the estimated concentrations of the oligomers, in particular.

Particle-phase products identified in the positive and negative ion modes revealed the presence of highly oxidized molecules not identified in the gas phase (Tables S3, S4 and Figure S3). The significant concentration of particle-phase products, such as 2-methyltetrols, indicate that observed gas-phase products might undergo further multiphase reactions in the presence of sulfate seed aerosols. Formation of oligomers in particle phase has been proposed to occur via esterification, aldol condensation and/or hemiacetal reactions (Nguyen et al., 2011). In addition, recent studies have reported that gaseous HOMs (e.g., multifunctional hydroperoxides) could undergo further multiphase reactions and/or acid-catalyzed hydrolysis to yield the formation of particle-phase oligomers (Lim and Turpin, 2015; Riva et al., 2016b) and OSs (Mutzel et al., 2015; Riva et al., 2016b). 
3.3 Impact of $\mathrm{OH}$ Scavenger on the Formation of Oligomeric Compounds.

Isoprene ozonolysis leads to $\mathrm{OH}$ radical formation with yields greater than $25 \%$ (Neeb and Moortgat, 1999); therefore, the OH-initiated oxidation of isoprene likely contributes to isoprene depletion. Under low- $\mathrm{NO}_{\mathrm{x}}$ conditions, $\mathrm{OH}$-initiated oxidation of isoprene produces organic peroxy radicals $\left(\mathrm{RO}_{2}\right)$ that can react with hydroperoxy radicals $\left(\mathrm{HO}_{2}\right)$ to form ISOPOOH isomers, which react further with $\mathrm{OH}$ radicals to give IEPOX in yields greater than 75\% (St. Clair et al., 2016). ISOPOOH and IEPOX are isobars and cannot be distinguished by the CIMS used in this work. Therefore, the parent ion at $m / z 245\left(\mathrm{C}_{5} \mathrm{H}_{10} \mathrm{O}_{3} \mathrm{I}^{-}\right)$is assigned to ISOPOOH and/or IEPOX and was observed in the experiments performed in the absence of diethyl ether. As shown in Figure S4, during the experiments performed in the presence of $\mathrm{OH}$ scavenger, the signal of the ion at $\mathrm{m} / \mathrm{z} 245$ was significantly reduced, confirming that most of the $\mathrm{OH}$ radicals were scavenged.

Tables 1 and S2 report the gas-phase products identified in the experiments performed in the presence of the $\mathrm{OH}$ scavenger. Compounds with changes in peak intensities $> \pm 30 \%$ in the presence and absence of $\mathrm{OH}$ radical scavenger were considered to be affected by the level of $\mathrm{OH}$ radical. In general, compounds belonging to the different groups are not significantly impacted by the presence of an $\mathrm{OH}$ scavenger. Similar peak intensities were observed except for compounds from Group 2 (Table 1), in which the signals of six oligomeric hydroperoxides decrease significantly in the presence of the $\mathrm{OH}$ scavenger (Figure 1a). The decrease of some products, such as the parent ion at $m / z 235\left(\mathrm{C}_{2} \mathrm{H}_{4} \mathrm{O}_{5} \mathrm{I}^{-}\right)$, is likely correlated with the decreased concentration of HPFOR, produced from the $\mathrm{OH}$-initiated oxidation of isoprene or its firstgeneration oxidation products. The decrease of other products, such as the parent ions at $\mathrm{m} / \mathrm{z}$ $277\left(\mathrm{C}_{5} \mathrm{H}_{10} \mathrm{O}_{5} \mathrm{I}^{-}\right), 279\left(\mathrm{C}_{4} \mathrm{H}_{8} \mathrm{O}_{6} \mathrm{I}^{-}\right)$and $293\left(\mathrm{C}_{5} \mathrm{H}_{10} \mathrm{O}_{6} \mathrm{I}^{-}\right)$, could be explained by the inhibition of isoprene oxidation by $\mathrm{OH}$ radicals (Figure 1a). Krechmer et al. (2015) reported the formation of gas-phase products with chemical compositions identical to the parent ions at 
$m / z 277,279$, and 293 from the OH-initiated oxidation of ISOPOOH. However, the HR-ToFCIMS cannot distinguish between isobars that might be formed from the oxidation of isoprene by $\mathrm{OH}$ radical and $\mathrm{O}_{3}$. As evident in Figure $1 \mathrm{~b}$ and Tables 1 and $\mathrm{S} 2$, the absence of $\mathrm{OH}$ radical could also enhance the formation of oligomeric products, such as parent ions at $\mathrm{m} / \mathrm{z}$ $237\left(\mathrm{C}_{2} \mathrm{H}_{6} \mathrm{O}_{5} \mathrm{I}^{-}\right)$and $251\left(\mathrm{C}_{2} \mathrm{H}_{4} \mathrm{O}_{6} \mathrm{I}^{-}\right)$. The increased abundance of these compounds might be explained by an increased depletion of isoprene by $\mathrm{O}_{3}$, and consequent increased formation of sCIs (formaldehyde oxide in the case of $\mathrm{C}_{2} \mathrm{H}_{6} \mathrm{O}_{5} \mathrm{I}^{-}$and $\mathrm{C}_{2} \mathrm{H}_{4} \mathrm{O}_{6} \mathrm{I}^{-}$, Figure $1 \mathrm{~b}$ ). Finally, larger abundance of such compounds could also be due to the lack of reactivity with $\mathrm{OH}$ radicals.

\subsection{Effect of Aerosol Composition on Gaseous Oligomeric Compounds.}

The fate of HOMs (including organic hydroperoxides), and oligomeric compounds such as those identified from isoprene ozonolysis (gas-particle partitioning, photolysis, reactive uptake, etc.) has received small attention and remains unclear. In order to better characterize their potential multiphase reactivity, the effects of seed aerosol composition as well as aerosol acidity were investigated. Figure 2 presents the time series of selected oligomeric compounds belonging to Groups 2 and 4 in the presence of acidified and neutral sulfate seed particles. No significant drop of the gas-phase ion signals after the injection of non-acidified $\left(\mathrm{NH}_{4}\right)_{2} \mathrm{SO}_{4}$ seed aerosols (at $\sim 350 \mathrm{~min}$ ) was observed for compounds reported in Tables 1 and S2. It is worth nothing that HOMs are expected to have low vapor pressures (Ehn et al., 2014; Li et al., 2016) and therefore to condense onto seed aerosol. However, Inomata et al. (2014) estimated that oligomeric hydroperoxides observed in the mass range of 120-160 have effective saturation concentrations of $10^{3} \mu \mathrm{g} \mathrm{m}^{-3}$ in the volatility basis model (Donahue et al., 2012). In addition, Kurten et al. (2016) have also been reported that group-contribution methods likely under-estimate the volatility of highly oxidized compounds by ignoring intramolecular H- 
bonds. Therefore, the lack of condensation suggests that observed species could be more volatile than previously expected.

Our experiments were performed at low RH and under these conditions non-acidified $\left(\mathrm{NH}_{4}\right)_{2} \mathrm{SO}_{4}$ seed aerosols are crystalline (Zelenuyk and Imre, 2005). Therefore, multiphase processes such as acid-catalyzed aqueous-phase reactions are significantly reduced or suppressed. The absence of SOA constituents derived from isoprene ozonolysis (Riva et al., $2016 \mathrm{a})$ in experiments performed using non-acidified $\left(\mathrm{NH}_{4}\right)_{2} \mathrm{SO}_{4}$ seed aerosols under dry conditions confirms the lack of multiphase chemistry. However, enhanced decomposition of organic peroxides was identified in the presence of SOA and water, suggesting that water affects the condensation or reactive uptake of organic hydroperoxides ( $\mathrm{Li}$ et al. 2016) onto seed aerosol.

Formation of oligomers and their OS derivatives was observed in the SOA generated from the reactive uptake of IEPOX in the presence of $\mathrm{MgSO}_{4}$ seed aerosol under dry conditions (Lin et al., 2014). Non-acidified $\mathrm{MgSO}_{4}$ aerosols do not effloresce at low-RH conditions and instead form gel-like chain structures of contact ion pairs (Chan et al., 2000). Figure $2 \mathrm{~b}$ shows that following the injection of non-acidified $\mathrm{MgSO}_{4}$ seed aerosols, only a slight decrease is observed in the concentration of gas-phase ions monitored at $\mathrm{m} / \mathrm{z} 251,281$ and 293, suggesting little condensation/reactive uptake. Acidified particles significantly enhanced the reactive uptake/condensation of gas-phase products reported in Tables 1 and S2. Figure 2 shows a drop of the gas-phase ion signals immediately following the injection of either acidified $\mathrm{MgSO}_{4}$ or $\left(\mathrm{NH}_{4}\right)_{2} \mathrm{SO}_{4}$ seed aerosols. The decrease of the concentrations of oligomeric compounds appears larger in the presence of acidified $\mathrm{MgSO}_{4}$ (Figure 2b) than acidified $\left(\mathrm{NH}_{4}\right)_{2} \mathrm{SO}_{4}$ seed aerosol (Figure 2a). Although the effects of aerosol acidity and liquid water content on the reactive uptake of oligomeric hydroperoxides cannot be deconvoluted because water is always present in the acidified seed particles, Figure 2 suggests 
that aerosol acidity promotes multiphase chemistry, as recently demonstrated for the reactive uptake of IEPOX (Gaston et al., 2014; Riedel et al., 2015). Consistent with this hypothesis and greater uptake by acidified $\mathrm{MgSO}_{4}$ seed aerosol observed in Figure 2, Lin et al. (2014) have estimated that under low-RH conditions, acidified $\mathrm{MgSO}_{4}$ seed aerosols are more acidic ( $\mathrm{pH} 0.62)$ than the acidified $\left(\mathrm{NH}_{4}\right)_{2} \mathrm{SO}_{4}$ seed aerosols $(\mathrm{pH} 2.25)$.

An increased concentration of gas-phase ions was also observed upon injection of acidified sulfate seed particles for a different set of products in Tables 1 and S2. As shown in Figures $3 \mathrm{a}$ and $3 \mathrm{~b}$, most of the products belonging to Group 3 as well as $\mathrm{CH}_{4} \mathrm{O}_{4} \mathrm{I}^{-}$were enhanced in the gas phase after the injection of acidic sulfate seed particles, while the addition of non-acidified seed particles did not impact the concentrations of these products. The reformation of these gaseous products is consistent with the acid-catalyzed decomposition of some oligomers formed by the insertion of sCIs into organic hydroperoxides or carboxylic acids and demonstrates the reactivity of such oligomeric products. It should be noted that the analytical techniques used in this study are not sensitive to volatile species such as small carbonyls (e.g. MACR or MVK) and as a consequence the importance of the re-volatilization is likely to be underestimated. Liu et al (2016) have also reported the decomposition of products of isoprene photooxidation in the presence of acidified sulfate aerosols with subsequent formation of volatile species, estimating that at least $50 \%$ of ISOPOOH taken up onto acidified aerosols react to form gas-phase species. In addition, the formation of hydrogen peroxide $\left(\mathrm{H}_{2} \mathrm{O}_{2}\right)$ was reported in high yield from the decomposition of organic hydroperoxides and/or HAHPs (Huang et al., 2013; Li et al., 2016). It is worth noting that a rise of gas-phase hydrogen peroxide ion signal $\left(\mathrm{IH}_{2} \mathrm{O}_{2}{ }^{-}\right)$was also observed in our experiments using only acidified seed particles, underlying the rapid decomposition of oligomeric hydroperoxides. The results presented here, combined with the existing literature, highlight the strong reactivity of hydroperoxides leading to volatile species that could undergo photooxidation 
processes and might further contribute to SOA formation. Reactive uptake of hydroperoxides could also proceed through accretion reactions to yield oligomers, OSs and 2-methyltetrols that have been identified in SOA generated from isoprene ozonolysis (Riva et al., 2016a).

Reaction time profiles of the main reactive gaseous species observed in the experiments performed with and without an $\mathrm{OH}$ scavenger using acidified sulfate seed aerosols are presented in Figure 4. The comparison of these two sets of experiments reveals that reactive uptake of the monitored species is significantly reduced by the presence of $\mathrm{OH}$ radicals. As mentioned earlier and shown in Figure S4, the absence of an $\mathrm{OH}$ radical scavenger induces the large formation of ISOPOOH/IEPOX in the gas phase. IEPOX and ISOPOOH chemistries have been intensively examined in recent studies and it has been demonstrated that IEPOX rapidly undergoes acid-catalyzed reactive uptake (Surratt et al., 2010; Gaston et al., 2014; Riedel et al., 2015) yielding significant SOA formation, whereas ISOPOOH $+\mathrm{OH}$ can also yield significant amounts of SOA through non-IEPOX channels (Liu et al., 2016; Riva et al., 2016b). However, reactive uptake of gas-phase epoxides could be significantly reduced by the presence of organic coatings on pre-existing aerosols (Gaston et al., 2014; Riva et al., 2016c). Therefore, the lack of reactivity of species in the experiments performed without an $\mathrm{OH}$ scavenger might be explained by the large formation of IEPOXderived SOA (Riva et al., 2016a). Hence, IEPOX chemistry could produce an organic coating and virtually halt further multiphase reactions of the oligomeric hydroperoxides. These results suggest that a potential competition exists between the multiphase reactivity of oxygenated species, and combined with a large presence of organics, might suppress any further multiphase chemistry of either gas-phase product.

\section{Conclusions}

Isoprene ozonolysis leads to the formation of sCIs in yields greater than 50\% (Newland et al., 2015; Nguyen et al., 2016). Although the importance of the plausible bimolecular reactions of 
sCIs remains unclear, formation of organic hydroperoxides, carboxylic acids and HOMs have been reported in different studies (Nguyen et al., 2010; Sakamoto et al., 2013; Inomata et al., 2014). The results presented here describe the formation of gas-phase oligomeric products through the insertion of sCIs into organic hydroperoxides and carboxylic acids and their subsequent reactive uptake onto acidified sulfate aerosols, which could lead to isoprenederived SOA products identified in laboratory and field experiments. In addition, HAHPs, formed from the reaction of sCIs with water, could also undergo further multiphase chemistry in the presence of acidified aerosols. Our results suggest that oligomeric products and hydroperoxides decompose in the presence of acidified sulfate aerosols to release volatile organic species (e.g. formic acid or $\mathrm{H}_{2} \mathrm{O}_{2}$ ), which could contribute to SOA or the oxidative capacity of the atmosphere through further photochemical chemical reactions. The multiphase reactivity can be suppressed by the build-up of an organic coating or by the lack of aerosol liquid water. Further experiments on the multiphase reactivity of organic hydroperoxides and HOMs are needed to better characterize these chemical processes and to estimate their impact on SOA formation. In particular, determination of the reaction probability $(\gamma)$ of epoxides and hydroperoxides onto varying aerosol compositions should be undertaken to better understand the multiphase chemistry of such reactive species. Finally, determination of the rate constants of the reaction between sCIs and acids and organic hydroperoxides should be systemically investigated to better evaluate the impact of sCI chemistry on SOA formation.

\section{Author Information}

Corresponding author: Jason D. Surratt

Email: surratt@unc.edu

Phone: 1-(919)-966-0470 


\section{Acknowledgements}

The authors wish to thank the Camille and Henry Dreyfus Postdoctoral Fellowship Program in Environmental Chemistry for financial support. This work is also funded in part by U.S. Environmental Protection Agency (EPA) grant R835404 and National Science Foundation grant CHE-1404644. The contents of this publication are solely the responsibility of the authors and do not necessarily represent the official views of the U.S. EPA. Further, the U.S. EPA does not endorse the purchase of any commercial products or services mentioned in the publication.

\section{References}

Berndt, T.; Jokinen, J.; Mauldin, III, R.L.; Petäjä, T.; Herrmann, H.; Junninen, H.; Paasonen, P. Worsnop, D.R.; Sipila, M. Gas-phase ozonolysis of selected olefins: the yield of stabilized Criegee intermediate and the reactivity toward $\mathrm{SO}_{2}$. J. Phys. Chem. Lett. 2012, 3, 2892-2896.

Berndt, T.; Voigtländer, J.; Stratmann, F.; Junninen, H.; Mauldin III, R.L.; Sipilä, M.; Kulmala, M.; Herrmann, H. Competing atmospheric reactions of $\mathrm{CH}_{2} \mathrm{OO}$ with $\mathrm{SO}_{2}$ and water vapour. Phys. Chem. Chem. Phys. 2014a, 16, 19130-19136.

Berndt, T.; Sipila, M.; Stratmann, F.; Petäjä, T.; Vanhanen, J.; Mikkilä J.; Patokoski, J.; Taipale, R.; Mauldin, III, R.L.; Kulmala, M. Enhancement of atmospheric $\mathrm{H}_{2} \mathrm{SO}_{4} / \mathrm{H}_{2} \mathrm{O}$ nucleation: organic oxidation products versus amines. Atmos. Chem. Phys. 2014b, 14, 751-764.

Bianchi, F.; Tröstl, J.; Junninen, H.; Frege, C.; Henne, S.; Hoyle, C.R.; Molteni, U.; Herrmann, E.; Adamov, A.; Bukowiecki, N.; Chen, X.; Duplissy, J.; Gysel, M.; Hutterli, M.; Kangasluoma, J.; Kontkanen, J.; Kürten, A.; Manninen, H.E.; Münch, S.; Peräkylä, O.; Petäjä, T.; Rondo, L.; Williamson, C.; Weingartner, E.; Curtius, J.; Worsnop, D.R.; Kulmala, M.; Dommen, J.; Baltensperger, U. New particle formation in the free troposphere: A question of chemistry and timing. Science 2016, 352, 1109-1112.

Budisulistiorini, S.H.; Canagaratna, M.R.; Croteau, P.L.; Marth, W.J.; Baumann, K.; Edgerton, E.S.; Shaw, S.L.; Knipping, E.M.; Worsnop, D.R.; Jayne, J.T.; Gold, A.; Surratt, J.D. Real-time continuous characterization of secondary organic aerosol derived from isoprene epoxydiols in downtown Atlanta, Georgia, using the aerodyne aerosol chemical speciation monitor. Environ. Sci. Technol. 2013, 47, 5686-5694.

Budisulistiorini, S.H.; Li, X.; Bairai, S.T.; Renfro, J.; Liu, Y.; Liu, Y.J.; McKinney, K.A.; Martin, S.T.; McNeill, V.F.; Pye, H.O.T.; Nenes, A.; Neff, M.E.; Stone, E.A.; Mueller, S.; Knote, C.; Shaw, S.L.; Zhang, Z.; Gold, A.; and Surratt, J.D. Examining the effects of anthropogenic emissions on 
isoprene-derived secondary organic aerosol formation during the 2013 Southern Oxidant and Aerosol Study (SOAS) at the Look Rock, Tennessee, ground site. Atmos. Chem. Phys. 2015, 15, 8871-8888.

Chan, C.K.; Ha, Z.; Choi, M.Y. Study of water activities of aerosols of mixtures of sodium and magnesium salts. Atmos. Environ. 2000, 34, 4795-4803.

Chen, Q.; Farmer, D.K.; Rizzo, L.V.; Pauliquevis, T.; Kuwata, M.; Karl, T.G.; Guenther, A.; Allan, J.D.; Coe, H.; Andreae, M.O.; Pöschl, U.; Jimenez, J.L.; Artaxo, P.; Martin, S.T. Submicron particle mass concentrations and sources in the Amazonian wet season (AMAZE-08). Atmos. Phys. Chem. 2015, 15, 3687-3701.

Czoschke, N.M.; Jang, M.; Kamens, R.M. Effect of acidic seed on biogenic secondary organic aerosol growth. Atmos. Environ. 2003, 37, 4287-4299.

Donahue, N.M.; Kroll, J.H.; Pandis, S.N.; Robinson, A.L. A two-dimensional volatility basis set - Part 2: Diagnostics of organic-aerosol evolution. Atmos. Chem. Phys. 2012, 12, 615-634.

Ehn, M.; Thornton, J.A.; Kleist, E.; Sipilä, M.; Junninen, H.; Pullinen, I.; Springer, M.; Rubach, F.; Tillmann, R.; Lee, B.; Lopez-Hilfiker, F.; Andres, S.; Acir, I.-H.; Rissanen, M.; Jokinen, T.; Schobesberger, S.; Kangasluoma, J.; Kontkanen, J.; Nieminen, T.; Kurtén, T.; Nielsen, L.B.; Jørgensen, S.; Kjaergaard, H.G.; Canagaratna, M.; Maso, M.D.; Berndt, T.; Petäjä, T.; Wahner, A.; Kerminen, V.-M.; Kulmala, M.; Worsnop, D.R.; Wildt, J.; Mentel, T.F. A large source of lowvolatility secondary organic aerosol. Nature 2014, 506, 476-479.

Gaston, C.J.; Riedel, T.P.; Zhang, Z.; Gold, A.; Surratt, J.D.; Thornton, J.A. Reactive uptake of an isoprene-derived epoxydiol to submicron aerosol particles. Environ. Sci. Technol. 2014, 48, 11178 11186.

Guenther, A. B.; Jiang, X.; Heald, C. L.; Sakulyanontvittaya, T.; Duhl, T.; Emmons, L. K.; Wang, X. The Model of Emissions of Gases and Aerosols from Nature version 2.1 (MEGAN2.1): an extended and updated framework for modeling biogenic emissions. Geosci Model Dev. 2012, 5, 1471-1492.

Hasson, A.S.; Ho, A.W.; Kuwata, K.T.; Paulson, S.E. Production of stabilized Criegee intermediates and peroxides in the gas phase ozonolysis of alkenes 2. Asymmetric and biogenic alkenes. J. Geophys. Res. Atmos. 2001, 106, 34143-34153.

Hu, W.W.; Campuzano-Jost, P.; Palm, B.B.; Day, D.A.; Ortega, A.M.; Hayes, P.L.; Krechmer, J.E.; Chen, Q.; Kuwata, M.; Liu, Y.J.; de Sá, S.S.; Martin, S.T.; Hu, M.; Budisulistiorini, S.H.; Riva, M.; Surratt, J.D.; St. Clair, J.M.; Isaacman-Van Wertz, G.; Yee, L.D.; Goldstein, A.H.; Carbone, S.; Artaxo, P.; de Gouw, J.A.; Koss, A.; Wisthaler, A.; Mikoviny, T.; Karl, T.; Kaser, L.; Jud, W.; Hansel, A.; Docherty, K.S.; Canagaratna, M.R.; Paulot, F.; Jimenez, J.L. Characterization of a real-time tracer for isoprene epoxydiols-derived secondary organic aerosol (IEPOX-SOA) from aerosol mass spectrometer measurements. Atmos. Chem. Phys. 2015, 15, 11807-11833.

Huang, D.; Chen, Z.M.; Zhao, Y.; Liang, H. Newly observed peroxides and the water effect on the formation and removal of hydroxyalkyl hydroperoxides in the ozonolysis of isoprene. Atmos. Chem. Phys. 2013, 13, 5671-5683. 
Inomata, S.; Sato, K.; Hirokawa, J.; Sakamoto, Y.; Tanimoto, H.; Okumura, M.; Tohno, S.; Imamura, T. Analysis of secondary organic aerosols from ozonolysis of isoprene by proton transfer reaction mass spectrometry. Atmos. Environ. 2014, 97, 397-405.

Jang, M.; Czoschke, N.M.; Lee, S.; Kamens, R.M. Heterogeneous atmospheric aerosol production by acid-catalyzed particle-phase reactions. Science 2002, 298, 814-817.

Johnson, D.; Marston, G. The gas-phase ozonolysis of unsaturated volatile organic compounds in the troposphere. Chem. Soc. Rev. 2008, 37, 699-716.

Kameel, F.R.; Hoffmann, M.R.; Colussi, A.J. OH Radical- initiated chemistry of isoprene in aqueous media. Atmospheric implications. J. Phys. Chem. A 2013, 117, 5117-5123.

Kamens, R.M.; Gery, M.W.; Jeffries, H.E.; Jackson, M.; Cole, E.I. Ozone-isoprene reactions: product formation and aerosol potential. Int. J. Chem. Kinet. 1982, 14, 955-975.

Kleindienst, T.E.; Lewandowski, M.; Offenberg, J.H.; Jaoui, M.; Edney, E.O. Ozone-isoprene reaction: Re-examination of the formation of secondary organic aerosol. Geophys. Res. Lett. 2007, 34, L01805.

Krechmer, J.E.; Coggon, M.M.; Massoli, P.; Nguyen, T.B.; Crounse, J.D.; Hu, W.; Day, D.A.; Tyndall, G.S.; Henze, D.K.; Rivera-Rios, J.C.; Nowak, J.B.; Kimmel, J.R.; Mauldin, R.L.; Stark, H.; Jayne, J.T.; Sipilä, M.; Junninen, H.; St. Clair, J.M.; Zhang, X.; Feiner, P.A.; Zhang, L.; Miller, D.O.; Brune, W.H.; Keutsch, F.N.; Wennberg, P.O.; Seinfeld, J.H.; Worsnop, D.R.; Jimenez, J.L.; Canagaratna, M.R. Formation of low volatility organic compounds and secondary organic aerosol from isoprene hydroxyhydroperoxide low-NO oxidation. Environ. Sci. Technol. 2015, 49, 10330-10339.

Kroll, J.H.; Seinfeld, J.H. Chemistry of secondary organic aerosol: formation and evolution of lowvolatility organics in the atmosphere. Atmos. Environ. 2008, 42, 3593-3624.

Kurten, T.; Tiusanen, K.; Roldin, P.; Rissanen, M.; Luy, J.-N.; Boy, M.; Ehn, M.; Donahue, N. $\alpha$ - Pinene autoxidation products may not have extremely low saturation vapor pressures despite high O:C ratios. J. Phys. Chem. A 2016, 120, 2569-2582.

Lee, B. H.; Lopez-Hilfiker, F.D.; Mohr, C.; Kurtén, T.; Worsnop, D.R.; Thornton, J.A. An iodideadduct high-resolution time-of-flight chemical-ionization mass spectrometer: Application to atmospheric inorganic and organic compounds. Environ. Sci. Technol. 2014, 48, 6309-6317.

Li, H.; Chen, Z.; Huang, L.; Huang, D. Organic peroxides gas-particle partitioning and rapid heterogeneous decomposition on secondary organic aerosol. Atmos. Chem. Phys. 2016, 16, 1837-1848.

Lim, Y.B.; Ziemann, P. Chemistry of secondary organic aerosol formation from $\mathrm{OH}$ radical-initiated reactions of linear, branched, and cyclic alkanes in the presence of $\mathrm{NO}_{\mathrm{x}}$. Aerosol Sci. Tech. 2009, 43, 604-619.

Lim, Y.B.; Turpin, B.J. Laboratory evidence of organic peroxide and peroxyhemiacetal formation in the aqueous phase and implications for aqueous OH. Atmos. Chem. Phys. 2015, 15, 12867-12877. 
Lin, Y.-H.; Zhang, Z.; Docherty, K.S.; Zhang, H.; Budisulistiorini, S.H.; Rubitschun, C.L.; Shaw, S.L.; Knipping, E.M.; Edgerton, E.S.; Kleindienst, T.E.; Gold, A.; Surratt, J.D. Isoprene epoxydiols as precursors to secondary organic aerosol formation: acid-catalyzed reactive uptake studies with authentic compounds. Environ. Sci. Technol. 2012, 46, 250-258.

Lin, Y.-H.; Budisulistiorini, S.H.; Chu, K.; Siejack, R.A.; Zhang, H.; Riva, M.; Zhang, Z.; Gold, A.; Kautzman, K.E.; Surratt, J.D. Light-absorbing oligomer formation in secondary organic aerosol from reactive uptake of isoprene epoxydiols. Environ. Sci. Technol. 2014, 48, 12012-12021.

Liu, Y.; Kuwata, M.; McKinner, K.A.; Martin S.T. Uptake and release of gaseous species accompanying the reactions of isoprene photo-oxidation products with sulfate particles. Phys. Chem. Chem. Phys. 2016, 18, 1595--600.

Lopez-Hilfiker, F.D.; Iyer, S.; Mohr, C.; Lee, B.H.; D'Ambro, E.L.; Kurtén, T.; Thornton, J.A. Constraining the sensitivity of iodide adduct chemical ionization mass spectrometry to multifunctional organic molecules using the collision limit and thermodynamic stability of iodide ion adducts. Atmos. Meas. Tech. 2016a, 9, 1505-1512.

Lopez-Hilfiker, F.D.; Mohr, C.; D'Ambro, E.L.; Lutz, A.; Riedel, T.P.; Gaston, C.J.; Iyer, S.; Zhang, Z.; Gold, A.; Surratt, J.D.; Lee, B.H.; Kurten, T.; Hu, W.W.; Jimenez, J.; Hallquist, M.; Thornton, J.A. Molecular composition and volatility of organic aerosol in the southeastern U.S.: implications for IEPOX derived SOA. Environ. Sci. Technol. 2016b, 50, 220-2209.

Mauldin III, R.L.; Berndt, T.; Sipilä, M.; Paasonen, P.; Petäjä, T.; Kim, S., Kurtén, T.; Stratmann, F.; Kerminen, V.-M.; Kulmala, M. A new atmospherically relevant oxidant. Nature 2012, 488, 193-196.

Mutzel, A.; Poulain, L.; Berndt, T.; Iinuma, Y.; Rodigast, M.; Böge, O.; Richters, S.; Spindler, G.; Sipila, M.; Jokinen, T.; Kulmala, M.; Herrmann, H. Highly oxidized multifunctional organic compounds observed in tropospheric particles: a field and laboratory study. Environ. Sci. Technol. 2015, 49, 7754-7761.

Neeb, P.; Sauer, F.; Horie, O.; Moortgat, G.K. Formation of hydroxymethyl hydroperoxide and formic acid in alkene ozonolysis in the presence of water vapour. Atmos. Environ. 1997, 31, 1417-1423.

Neeb, P.; Moortgat, G.K. Formation of OH radicals in the gas-phase reaction of propene, isobutene, and isoprene with $\mathrm{O}_{3}$ : Yields and mechanistic implications. J. Phys. Chem. A 1999, 103, 9003-9012.

Newland, M.J.; Rickard, A.R.; Alam, M.S.; Vereecken, L.; Muñoz, A.; Ródenas, M.; Bloss, W.J. Kinetics of stabilised Criegee intermediates derived from alkene ozonolysis: reactions with $\mathrm{SO}_{2}, \mathrm{H}_{2} \mathrm{O}$ and decomposition under boundary layer conditions. Phys. Chem. Chem. Phys 2015, 17, 4076-4088.

Nguyen, T.B.; Bateman, A.P.; Bones, D.L.; Nizkorodov, S.A.; Laskin, J.; Laskin, A. High-resolution mass spectrometry analysis of secondary organic aerosol generated by ozonolysis of isoprene. Atmos. Environ. 2010, 44, 1032-1042.

Nguyen, T.B.; Roach, P.J.; Laskin, J.; Laskin, A.; Nizkorodov, S.A. Effect of humidity on the composition of isoprene photooxidation secondary organic aerosol. Amos. Chem. Phys. 2011, 11, 6931-6944. 
Nguyen, T.B.; Tyndall, G.S; Crounse, J.D.; Teng, A.P.; Bates, K.H.; Schwantes, R.H.; Coggon, M.M.; Zhang, L.; Feiner, P.; Milller, D.O.; Skog, K.M.; Rivera-Rios, J.C.; Dorris, M.; Olson, K.F.; Koss, A.; Wild, R.J.; Brown, S.S.; Goldstein, A.H.; De Gouw, J.A.; Brune, W.H.; Keutsch, F.N.; Seinfeld, J.H.; Wennberg, P.O. Atmospheric fates of Criegee intermediates in the ozonolysis of isoprene. Phys. Chem. Chem. Phys. 2016, 18, 10241-10254.

Novelli, A.; Vereecken, L.; Lelieveld, J.; Harder, H. Direct observation of OH formation from stabilised Criegee intermediates. Phys. Chem. Chem. Phys. 2014, 16, 19941-19951.

Orzechowska, G.E.; Paulson, S.E. Production of $\mathrm{OH}$ radicals from the reactions of $\mathrm{C}_{4}-\mathrm{C}_{6}$ internal alkenes and styrenes with ozone in the gas phase. Atmos. Environ. 2002, 36, 571-581.

Rattanavaraha, W.; Chu, K.; Budisulistiorini, S.H.; Riva, M.; Lin, Y.-H.; Edgerton, E.S.; Baumann, K.; Shaw, S.L.; Guo, H.; King, L.; Weber, R.J.; Stone, E.A.; Neff, M.E.; Offenberg, J.H.; Zhang, Z.; Gold, A.; Surratt, J.D. Assessing the impact of anthropogenic pollution on isoprene-derived secondary organic aerosol formation in PM2.5 collected from the Birmingham, Alabama ground site during the 2013 Southern Oxidant and Aerosol Study. Atmos. Phys. Chem. 2016, 16, 4897-4914.

Riedel, T.P.; Lin, Y.-H.; Budisulistiorini, S.H.; Gaston, C.J.; Thornton, J.A.; Zhang, Z.; Vizuete, W.; Gold, A.; Surratt, J.D. Heterogeneous reactions of isoprene-derived epoxides: reaction probabilities and molar secondary organic aerosol yield estimates. Environ. Sci. Technol. Lett. 2015, 2, 38-42.

Riva, M.; Budisulistiorini, S.H.; Zhang, Z.; Gold, A.; Surratt, J.D. Chemical characterization of secondary organic aerosol constituents from isoprene ozonolysis in the presence of acidic aerosol. Atmos. Environ. 2016a, 130, 5-13.

Riva, M.; Budisulistiorini, S.H.; Chen, Y.; Zhang, Z.; D’Ambro, E.L.; Zhang, X.; Gold, A.; Turpin, B.J.; Thornton, J.A.; Canagaratna, M.R.; J.D. Surratt. Chemical characterization of secondary organic aerosol from oxidation of isoprene hydroxyhydroperoxides. Environ. Sci. Technol. 2016b, 50, 98899899.

Riva, M.; Bell, D.M.; Hansen, A.M.K.; Drozd, G.T.; Zhenfa, Z.; Gold, A.; Imre, D.; Surratt, J.D.; Glasius, M.; Zelenyuk, A. Effect of organic coatings, humidity and aerosol acidity on multiphase chemistry of isoprene epoxydiols. Environ. Sci. Technol. 2016c, 50, 5580-5588.

Sakamoto, Y.; Inomata, S.; Hirokawa, J. Oligomerization reaction of the Criegee intermediate leads to secondary organic aerosol formation in ethylene ozonolysis. J. Phys. Chem A 2013, 117, 12912-12921.

Sato, K.; Inomata, S.; Xing, J.-H.; Imamura, T.; Uchida, R.; Fukuda, S.; Nakagawa, K.; Hirokawa, J.; Okumura, M.; Tohno, S. Effect of $\mathrm{OH}$ radical scavengers on secondary organic aerosol formation from reactions of isoprene with ozone. Atmos. Environ. 2013, 79, 147-154.

Sauer, F.; Schäfer, C.; Neeb, P.; Horie, O.; Moortgat, G.K. Formation of hydrogen peroxide in the ozonolysis of isoprene and simple alkenes under humid conditions. Atmos. Environ. 1999, 33, 229241.

Sipilä, M.; Jokinen, T.; Berndt, T.; Richters, S.; Makkonen, R.; Donahue, N.M.; Mauldin III, R.L.; Kurtén, T.; Paasonen, P.; Sarnela, N.; Ehn, M.; Junninen, H.; Rissanen, M.P.; Thornton, J.; Stratmann, 
F.; Herrmann, H.; Worsnop, D.R.; Kulmala, M.; Kerminen, V.-M.; Petäjä, T. Reactivity of stabilized Criegee intermediates (sCIs) from isoprene and monoterpene ozonolysis toward toward $\mathrm{SO}_{2}$ and organic acids. Atmos. Chem. Phys. 2014, 14, 12143-12153.

Szmigielski, R. Evidence for $\mathrm{C}_{5}$ organosulfur secondary organic aerosol components from in-cloud processing of isoprene: Role of reactive $\mathrm{SO}_{4}$ and $\mathrm{SO}_{3}$ radicals. Atmos. Environ. 2016, 130, 14-22.

St. Clair, J.M.; Rivera-Rios, J.C.; Crounse, J.D.; Knap, H.C.; Bates, K.H.; Teng, A.P.; Jorgensen, S.; Kjaergaard, H.G.; Keutsch, F.N.; Wennberg, P.O. Kinetics and products of the reaction of the firstgeneration isoprene hydroxy hydroperoxide (ISOPOOH) with OH. J. Phys. Chem. A 2016, 120, 14411451.

Surratt, J.D.; Chan, A.W.H.; Eddingsaas, N.C.; Chan, M.; Loza, C.L.; Kwan, A.J.; Hersey, S.P.; Flagan, R.C.; Wennberg, P.O.; Seinfeld, J.H. Reactive intermediates revealed in secondary organic aerosol formation from isoprene. Proc. Natl. Acad. Sci. 2010, 107, 6640-6645.

Taatjes, C.A.; Welz, O.; Eskola, A.J.; Savee, J.D.; Osborn, D.L.; Lee, E.P.F.; Dyke, J.M.; Mok, D.W.K.; Shallcross, D.E.; Percival, C.J. Direct measurements of Criegee intermediate $\left(\mathrm{CH}_{2} \mathrm{OO}\right)$ formed by reaction of $\mathrm{CH}_{2} \mathrm{I}$ with $\mathrm{O}_{2}$. Phys. Chem. Chem. Phys. 2012, 14, 10391-10400.

Taatjes, C.A.; Welz, O.; Eskola, A.J.; Savee, J.D.; Scheer, A.M.; Shallcross, D.E.; Rotavera, B.; Lee, E.P.F.; Dyke, J.M.; Mok, D.K.W.; Osborn, D.L.; Percival, C.J. Direct measurements of conformerdependent reactivity of the Criegee intermediate $\mathrm{CH}_{3} \mathrm{CHOO}$. Science 2013, 340, 177-180.

Wang, H.L.; Huang, D.; Zhang, X.; Zhao, Y.; Chen, Z.M. Understanding the aqueous phase ozonolysis of isoprene: distinct product distribution and mechanism from the gas phase reaction. Atmos. Chem. Phys. 2012, 12, 7187-7198.

Welz, O.; Savee, J.D.; Osborn, D.L.; Vasu, S.S.; Percival, C.J.; Shallcross, D.E.; Taatjes, C.A. Direct kinetic measurements of Criegee intermediate $\left(\mathrm{CH}_{2} \mathrm{OO}\right)$ formed by reaction of $\mathrm{CH}_{2} \mathrm{I}$ with $\mathrm{O}_{2}$. Science 2012, 335, 204-207

Welz, O.; Eskola, A.J.; Sheps, L.; Rotavera, B.; Savee, J.D.; Scheer, A.M.; Osborn, D.L.; Lowe, D.; Murray Booth, A.; Xiao, P.; Anwar H.; Khan, M.; Percival, C.J.; Shallcross, D.E.; Taatjes, C.A. Rate coefficients of $\mathrm{C}_{1}$ and $\mathrm{C}_{2}$ Criegee intermediate reactions with formic and acetic acid near the collision limit: direct kinetics measurements and atmospheric implications. Angew. Chem. Int. Ed. Engl. 2014, $53,4547-4550$.

Xu, L.; Guo, H.; Boyd, C.M.; Klein, M.; Bougiatioti, A.; Cerully, K.M.; Hite, J.R.; IsaacmanVanWertz, G.; Kreisberg, N.M.; Knote, C.; Olson, K.; Koss, A.; Goldstein, A.H.; Hering, S.V.; De Gouw, J.; Baumann, K.; Lee, S.-H.; Nenes, A.; Weber, R.J.; Ng, N.L. Effects of anthropogenic emissions on aerosol formation from isoprene and monoterpenes in the southeastern United States. Proc. Natl. Acad. Sci. 2015, 112, 37-42.

Zelenyuk, A.; Imre, D. Single particle laser ablation time-of-flight mass spectrometer: An introduction to SPLAT. Aerosol Sci. Tech. 2005, 39, 554-568. 
Zhang, D.; Lei, W.; Zhang, R. Mechanism of OH formation from ozonolysis of isoprene: kinetics and product yield. Chem. Phys. Lett. 2002, 358, 171-179. 
Table 1. Accurate mass fittings of organic hydroperoxides and sCI-hydroperoxide oligomers identified from the ozonolysis of isoprene.

\begin{tabular}{|c|c|c|c|c|c|c|}
\hline $\begin{array}{c}\text { Measured } \\
m / z\end{array}$ & $\begin{array}{c}\text { Proposed } \\
\text { Formula }\end{array}$ & $\underset{\mathbf{a}}{\mathbf{D B E}}$ & Name/Reaction & $\begin{array}{c}\text { Reactive } \\
\text { Uptake }\end{array}$ & Sca $^{b}$ & $\begin{array}{l}\text { UPLC/ESI } \\
\text {-QTOFMS }\end{array}$ \\
\hline \multicolumn{7}{|c|}{ Group 1: Hydroperoxides } \\
\hline 188.897 & $\mathrm{CH}_{2} \mathrm{O}_{3} \mathrm{I}^{-}$ & 1 & HPFOR & - & - & \\
\hline 190.911 & $\mathrm{CH}_{4} \mathrm{O}_{3} \mathrm{I}^{-}$ & 0 & НMHР & & & $(\mathrm{M}+\mathrm{H})^{+}$ \\
\hline 204.905 & $\mathrm{CH}_{2} \mathrm{O}_{4} \mathrm{I}^{-}$ & 1 & HPFA & - & & \\
\hline 206.910 & $\mathrm{CH}_{4} \mathrm{O}_{4} \mathrm{I}^{-}$ & 0 & HPMP & + & & \\
\hline 228.940 & $\mathrm{C}_{4} \mathrm{H}_{6} \mathrm{O}_{3} \mathrm{I}^{-}$ & 2 & HPMVK/HPMACR & + & - & \\
\hline $232.921^{\mathrm{c}}$ & $\mathrm{C}_{3} \mathrm{H}_{6} \mathrm{O}_{4} \mathrm{I}^{-}$ & 1 & HPLA/HPHA & - & + & $(\mathrm{M}+\mathrm{H})^{-}$ \\
\hline \multicolumn{7}{|c|}{ Group 2: Oligomeric Hydroperoxides } \\
\hline 234.913 & $\mathrm{C}_{2} \mathrm{H}_{4} \mathrm{O}_{5} \mathrm{I}^{-}$ & 1 & $\mathrm{HPFOR}+\mathrm{C}_{1}$-sCI & & - & \\
\hline 236.929 & $\mathrm{C}_{2} \mathrm{H}_{6} \mathrm{O}_{5} \mathrm{I}^{-}$ & 0 & $\mathrm{HMHP}+\mathrm{C}_{1}$-sCI & + & + & \\
\hline 250.915 & $\mathrm{C}_{2} \mathrm{H}_{4} \mathrm{O}_{6} \mathrm{I}^{-}$ & 1 & $\mathrm{HPFA}+\mathrm{C}_{1}-\mathrm{sCI}$ & - & + & $(\mathrm{M}+\mathrm{H})^{+}$ \\
\hline 252.951 & $\mathrm{C}_{2} \mathrm{H}_{6} \mathrm{O}_{6} \mathrm{I}^{-}$ & 0 & $\mathrm{HPMP}+\mathrm{C}_{1}-\mathrm{sCI}$ & & & \\
\hline $274.948^{\mathrm{c}}$ & $\mathrm{C}_{5} \mathrm{H}_{8} \mathrm{O}_{5} \mathrm{I}^{-}$ & 2 & HPMVK/HPMACR $+\mathrm{C}_{1}$-sCI & & - & \\
\hline 276.995 & $\mathrm{C}_{5} \mathrm{H}_{10} \mathrm{O}_{5} \mathrm{I}$ & 1 & $\mathrm{HMHP}+\mathrm{C}_{4}$-sCI & - & - & \\
\hline $278.933^{c}$ & $\mathrm{C}_{4} \mathrm{H}_{8} \mathrm{O}_{6} \mathrm{I}^{-}$ & 1 & HPLA/HPHA $+\mathrm{C}_{1}$-sCI & - & - & \\
\hline 280.912 & $\mathrm{C}_{3} \mathrm{H}_{6} \mathrm{O}_{7} \mathrm{I}^{-}$ & 1 & $\mathrm{HPFOR}+2\left(\mathrm{C}_{1}-\mathrm{sCI}\right)$ & - & + & \\
\hline 282.938 & $\mathrm{C}_{3} \mathrm{H}_{8} \mathrm{O}_{7} \mathrm{I}^{-}$ & 0 & $\mathrm{HMHP}+2\left(\mathrm{C}_{1}-\mathrm{sCI}\right)$ & & & $(\mathrm{M}+\mathrm{H})^{+}$ \\
\hline 292.959 & $\mathrm{C}_{5} \mathrm{H}_{10} \mathrm{O}_{6} \mathrm{I}$ & 1 & $\mathrm{HPMP}+\mathrm{C}_{4}-\mathrm{SCI}$ & - & - & \\
\hline 298.928 & $\mathrm{C}_{3} \mathrm{H}_{8} \mathrm{O}_{8} \mathrm{I}^{-}$ & 0 & $\mathrm{HPMP}+2\left(\mathrm{C}_{1}-\mathrm{sCI}\right)$ & - & - & \\
\hline
\end{tabular}

${ }^{a} D B E$ : double bond equivalent; ${ }^{b}$ Sca: experiments performed using an OH radical scavenger; ${ }^{c}$ Compound could be formed from reaction of an sCI with an organic acid (Table S2); in the columns "reactive uptake" and "Sca", (+) or (-) denotes decrease and increase of peak intensity, respectively. HPFOR: hydroperoxide formaldehyde; HMHP: hydroxymethyl hydroperoxide; HPFA: hydroxyperformic acid; HPMP: hydroperoxy methyl hydroperoxide; HPMVK/HPMACR: hydroperoxy methyl vinyl ketone/ hydroperoxy methacrolein; HPLA: hydroperoxy lactaldehyde; HPHA: hydroperoxy hydroxyacetone. 

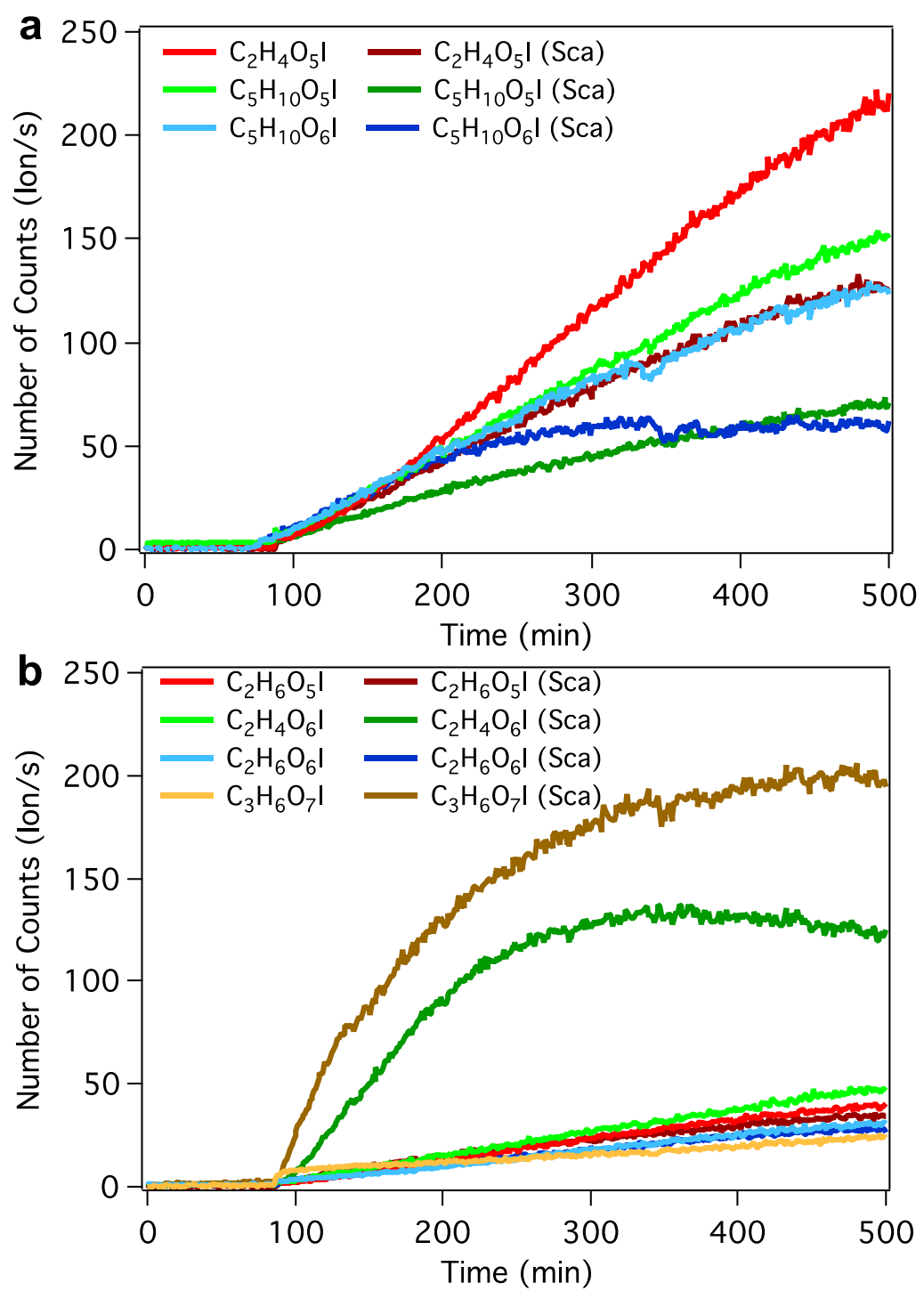

Figure 1. Time series of oligomeric products belonging to Group 2 formed by the insertion of sCIs into organic hydroperoxides (Table 1). Panels (a) and (b) show the impact of an $\mathrm{OH}$ radical scavenger (Sca) on the formation of the gas-phase products in the presence of nonacidified magnesium sulfate seed aerosols injected after $\sim 350 \mathrm{~min}$. 

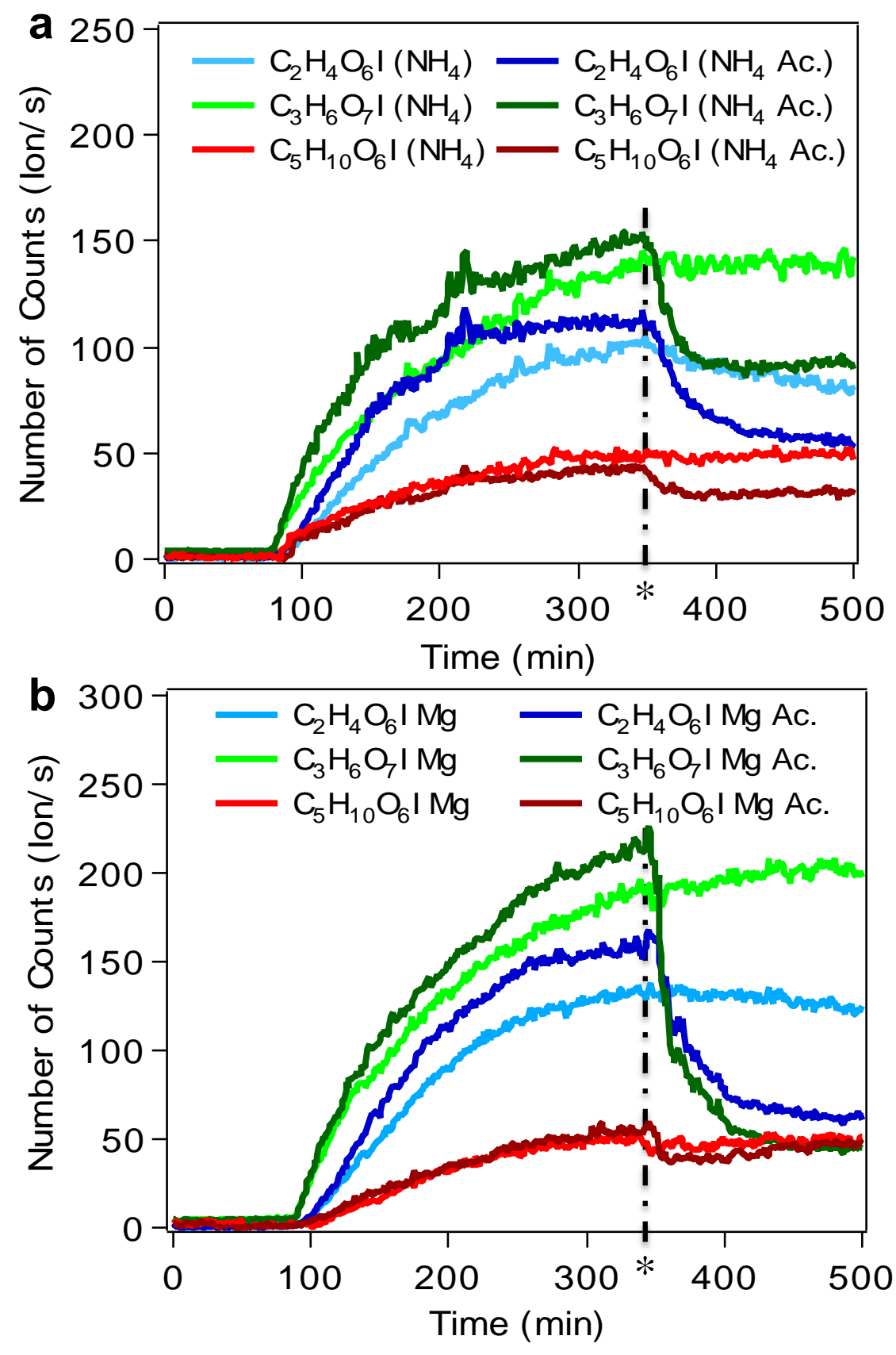

Figure 2. Time series of gas-phase products belonging to Group 2 formed from isoprene ozonolysis in the presence of an $\mathrm{OH}$ radical scavenger. (a) Non-acidified $\left(\mathrm{NH}_{4}\right)$ and acidified $\left(\mathrm{NH}_{4}\right.$ Ac.) ammonium sulfate and (b) non-acidified $(\mathrm{Mg})$ and acidified (Mg Ac.) magnesium sulfate aerosols were injected after $\sim 350 \mathrm{~min}$ (* indicates the injection of seed particles). 

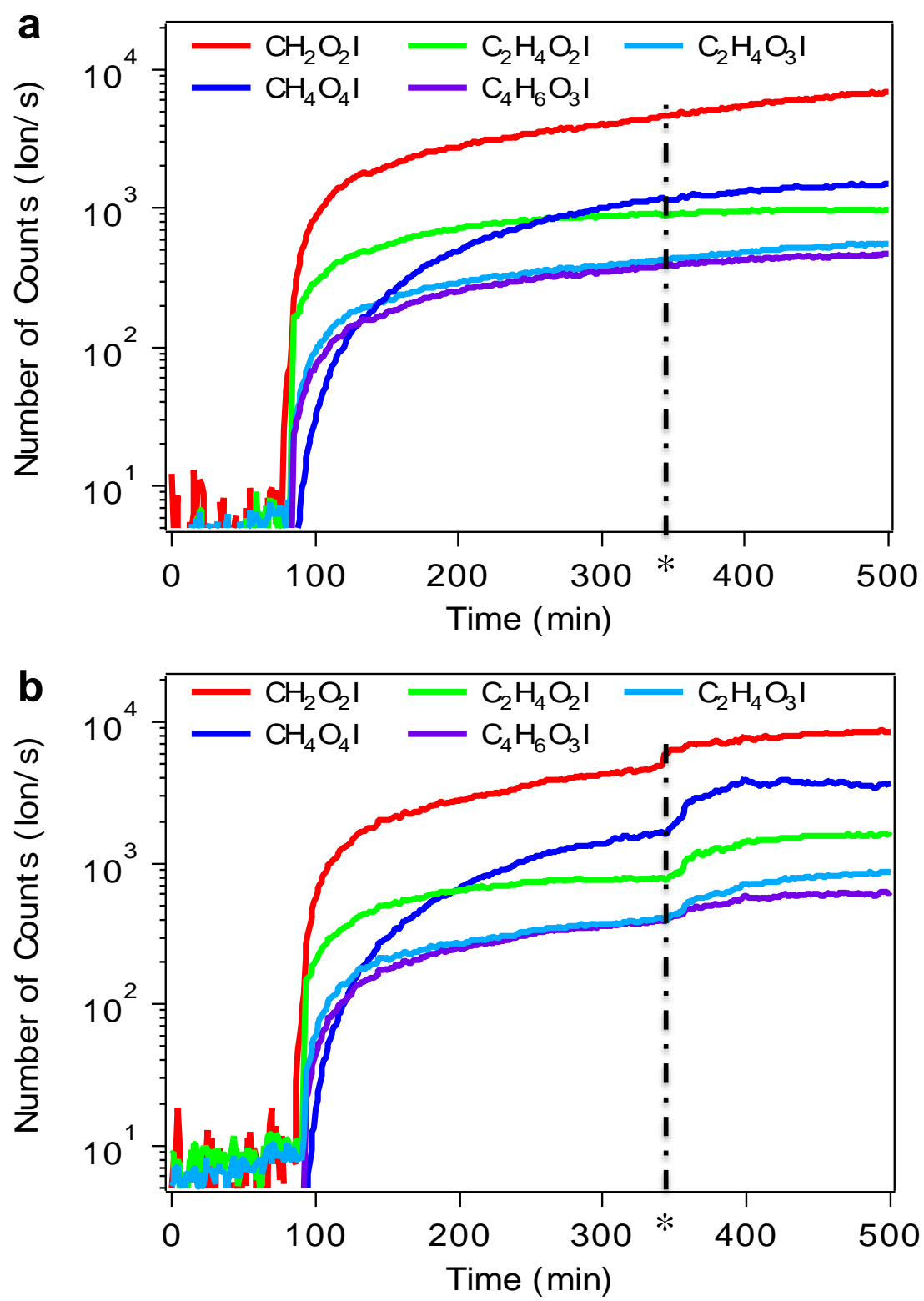

Figure 3. Time profiles of selected organic hydroperoxides and carboxylic acids formed by isoprene ozonolysis in the presence of an $\mathrm{OH}$ scavenger. Panels (a) and (b) correspond to experiments performed using non-acidified and acidified magnesium sulfate seed aerosols, respectively. Seed aerosols were injected after $\sim 350 \mathrm{~min}(*$ indicates the injection of seed particles)). 


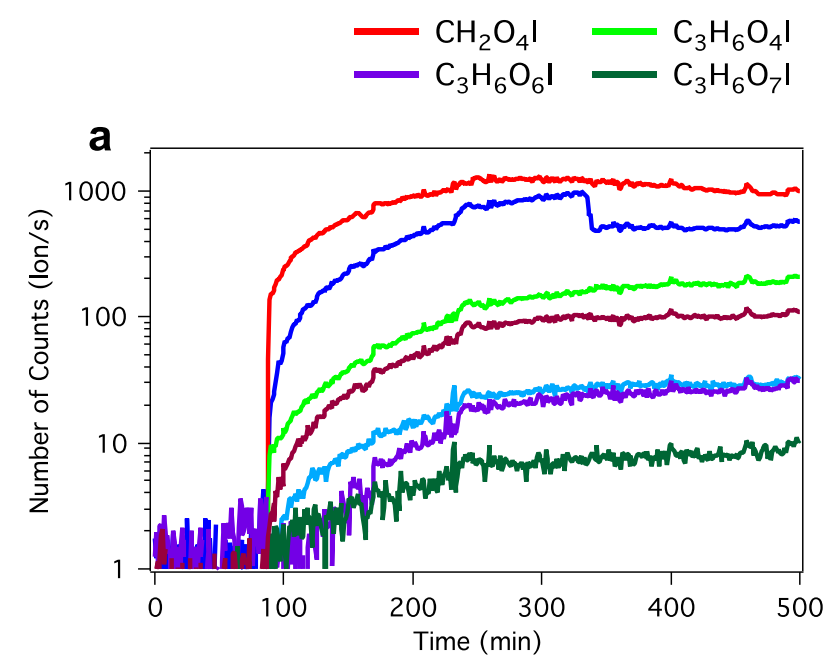

$$
-\mathrm{C}_{2} \mathrm{H}_{4} \mathrm{O}_{6} \mathrm{I}-\mathrm{C}_{5} \mathrm{H}_{8} \mathrm{O}_{4} \mathrm{I}
$$

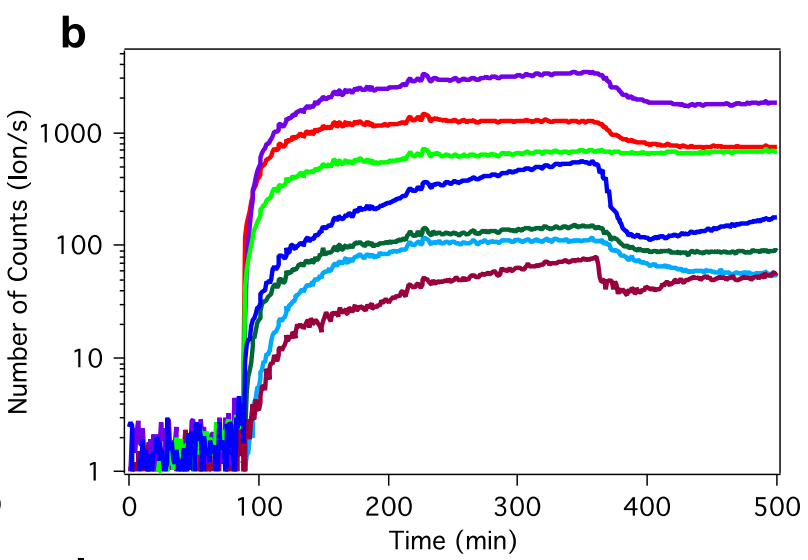

C

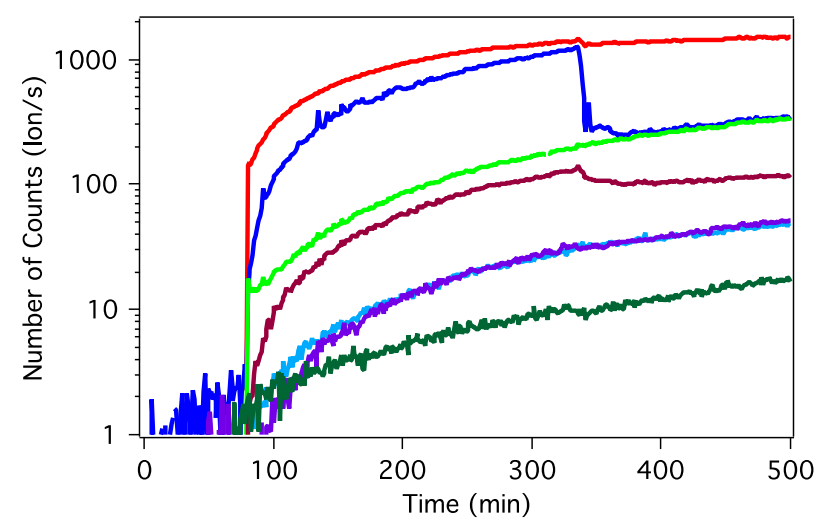

d

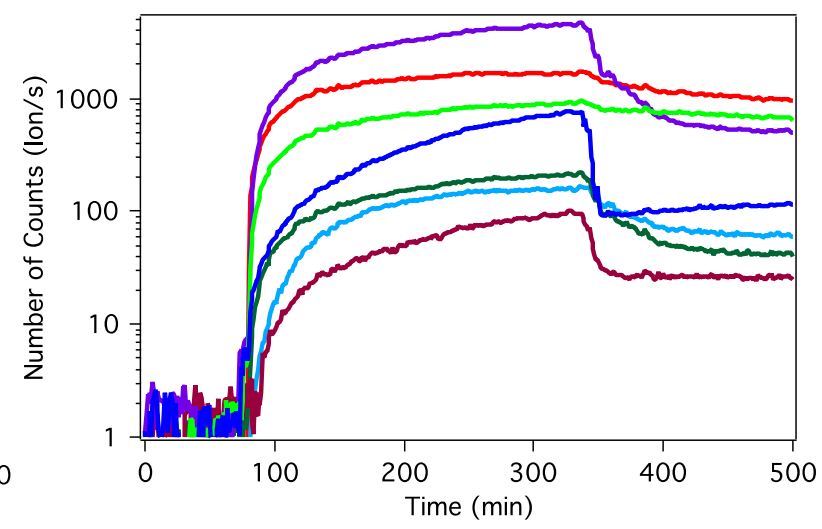

Figure 4. Time profiles of the major reactive gaseous species in the presence of acidified sulfate seed aerosols identified generated by isoprene ozonolysis. Panels (a) and (b) correspond to the experiments performed using acidified ammonium sulfate seed particles without and with an $\mathrm{OH}$ radical scavenger, respectively. Panels (c) and (d) correspond to the experiments performed using acidified magnesium seed particles without and with an $\mathrm{OH}$ radical scavenger, respectively. Seed aerosols were injected after $\sim 350 \mathrm{~min}$. 